Article

\title{
Exploring the Antibacterial Activity of Pestalotiopsis spp. under Different Culture Conditions and Their Chemical Diversity Using LC-ESI-Q-TOF-MS
}

\author{
Madelaine M. Aguilar-Pérez ${ }^{1, \dagger}{ }^{\text {, Daniel Torres-Mendoza }}{ }^{1,2,+} \mathbb{C}$, Roger Vásquez ${ }^{1}$, Nivia Rios ${ }^{3}$ \\ and Luis Cubilla-Rios ${ }^{1, *(\mathbb{D})}$ \\ 1 Laboratory of Tropical Bioorganic Chemistry, Faculty of Natural, Exact Sciences and Technology, \\ University of Panama, Panama 0824, Panama; mad25aguilar@gmail.com (M.M.A.-P.); \\ dtorresm.507@gmail.com (D.T.-M.); royi071123@gmail.com (R.V.) \\ 2 Vicerrectoría de Investigación y Postgrado, University of Panama, Panama 0824, Panama \\ 3 Department of Microbiology, Faculty of Natural, Exact Sciences and Technology, University of Panama, \\ Panama 0824, Panama; toxogondii@gmail.com \\ * Correspondence: luis.cubilla@up.ac.pa; Tel.: +507-6676-5824 \\ + These authors contributed equally to this work.
}

Received: 16 July 2020; Accepted: 17 August 2020; Published: 19 August 2020

check for updates

\begin{abstract}
As a result of the capability of fungi to respond to culture conditions, we aimed to explore and compare the antibacterial activity and chemical diversity of two endophytic fungi isolated from Hyptis dilatata and cultured under different conditions by the addition of chemical elicitors, changes in the $\mathrm{pH}$, and different incubation temperatures. Seventeen extracts were obtained from both Pestalotiopsis mangiferae (man-1 to man-17) and Pestalotiopsis microspora (mic-1 to mic-17) and were tested against a panel of pathogenic bacteria. Seven extracts from $P$. mangiferae and four extracts from $P$. microspora showed antibacterial activity; while some of these extracts displayed a high-level of selectivity and a broad-spectrum of activity, Pseudomonas aeruginosa was the most inhibited microorganism and was selected to determine the minimal inhibitory concentration (MIC). The MIC was determined for extracts man-6 $(0.11 \mu \mathrm{g} / \mathrm{mL})$ and mic-9 $(0.56 \mu \mathrm{g} / \mathrm{mL})$. Three active extracts obtained from $P$. mangiferae were analyzed by Liquid Chromatography-Electrospray Ionization-Quadrupole-Time of Flight-Mass Spectrometry (LC-ESI-Q-TOF-MS) to explore the chemical diversity and the variations in the composition. This allows us to propose structures for some of the determined molecular formulas, including the previously reported mangiferaelactone (1), an antibacterial compound.
\end{abstract}

Keywords: Endophytic fungi; Hyptis dilatata; Pestalotiopsis mangiferae; Pestalotiopsis microspora; chemical elicitors; antibacterial activity; LC-ESI-Q-TOF-MS

\section{Introduction}

The World Health Organization (WHO; Geneva, Switzerland) has established an urgent pathogen list of antibiotic-resistant bacteria to guide the research, discovery, and development of new antibiotics. This list includes carbapenem-resistant Pseudomonas aeruginosa and Enterobacteriaceae and third generation cephalosporin-resistant bacteria as critical priorities as a result of the continuous and indiscriminate use of antibiotics, not only in the treatment of human diseases, but also in animals $[1,2]$. This list includes antifungal compounds [3].

Pharmaceutical conglomerates have abandoned this field of research due to the high costs. Despite the efforts made in recent years, e.g., investment in research and development (R\&D) as well as in scientific and technological research, the strategies for the search of new antibiotics and antifungals 
remain uncertain $[4,5]$. In this context, natural products produced by endophytic fungi provide an alternative to supply new molecules with antimicrobial activities [6-9].

Endophytic fungi spend a large part of their life cycle inside the tissue of the host organism without causing apparent damage [10]. In the last 15 years, interest in endophytic fungi has grown exponentially because of their ability to produce a wide range of secondary metabolites with diverse and important biological activities. Plant endophytes are considered one of the least studied groups of microorganisms and have proven to be a source of natural products and therefore provide a way to discover novel compounds with biological activities [11,12]. Two species of the genus Pestalotiopsis, isolated from Hyptis dilatata (Labiatae), a plant that is distributed in the north and east of the Republic of Panama and that is known for producing abietane and pimarane diterpenes [13] were selected for these studies.

The genus Pestalotiopsis is considered a vast source of natural products from which more than 300 compounds have been isolated and characterized, including terpenoids, polyketides, chromones, quinones, coumarins, lactones, and nitrogen-containing molecules with a wide range of biological activities such as antifungal, antibacterial, anticancer, antioxidant, antiparasitic, antihypertensive, anti-inflammatory, and neuroprotective activities [14-19]. Previously, our group reported the isolation of a set of eleven compounds (see Figure S1) from the crude extract of P. mangiferae, including a polyhydroxylated macrolide named mangiferaelactone [20]; the crude extract showed growth inhibition against Listeria monocytogenes ( $29 \mathrm{~mm}$ diameter inhibition zone), and showed a minimal inhibitory concentration (MIC) of $1.69 \mathrm{mg} / \mathrm{mL}$ and $0.55 \mathrm{mg} / \mathrm{mL}$ against L. monocytogenes and Bacillus cereus, respectively. This compound belongs to the nonalide class that is associated with important biological activities such anticancer, antifungal, antibacterial, and antiviral activities. Its synthesis has been developed by different research groups [21-23]. Compounds such as taxol, isopestacin, and some polyketides have been isolated from P. microspora [24-27].

The production of secondary metabolites by microorganisms could be impacted by environmental dynamics, such as growing conditions, which include biotic and abiotic factors [28]. Therefore, the selective variation of these parameters during the cultivation of fungi $[29,30]$ and/or the induction of stress through competition with other microorganisms in a co-culture represent interesting ways to generate greater activity, chemical diversity, and novel active molecules [31-33]. Hence, the opportunity to modify culture conditions allows for the optimization of secondary metabolite production [34]. Therefore, given the growing interest in enhancing the production of secondary metabolites by endophytic fungi, the study of the methods and strategies to stimulate the gene clusters responsible for the biosynthesis of new molecules has been intensified and could include chemical or physical factors [35,36]. For example, the use of metallic ions, organic and inorganic compounds, $\mathrm{pH}$, and incubation temperature to optimize the production of enzymes or secondary metabolites have been described [37-47].

For this study, we focused on modifying the conditions of the culture medium by varying abiotic parameters and through this, activate fungal silent gene clusters [48-50] in P. mangiferae Hd08 and P. microspora Hd18 in order to increase the chemical diversity and to detect new antibacterial activities.

\section{Materials and Methods}

\subsection{Chemicals and Reagents}

All of the following chemicals were acquired from Sigma-Aldrich ${ }^{\circledR}$ (Sigma-Aldrich, St. Louis, $\mathrm{MO}$, USA): arginine, glutamic acid, $\mathrm{CuSO}_{4}, \mathrm{CaCl}_{2}, \mathrm{FeSO}_{4}$, tri-sodium citrate dihydrate, dimethyl sulfoxide (DMSO), and formic acid (FA). Ethyl acetate, acetone, and methanol used for extraction were American Chemical Society grade (Tedia ${ }^{\circledR}$, Tedia Company Inc., Fairfield, OH, USA). The methanol for the liquid chromatography-mass spectrometry (LC-MS) analysis was LC-MS grade (J. T. Baker ${ }^{\circledR}$, Avantor Performance Materials, Inc., Center Valley, PA, USA). 


\subsection{Isolation and Identification of Fungal Isolates}

A healthy specimen of Hyptis dilatata (Labiatae) was collected in La Mesa, Veraguas Province in the Republic of Panama, in November 2010. An exsiccate from the plant material was deposited in the Herbarium of the University of Panama (PMA 084861). Mature leaves were surface sterilized as we previously reported in [51], and small fragments were cultured on $2 \%$ malt-extract agar (MEA; Difco $^{\mathrm{TM}}$, Becton, Dickinson and Co., Sparks, MD, USA) under sterile conditions. Strains Hd08 and Hd18 were further isolated from the collection plate and successively re-plated until pure strains were obtained. Pure fungal strains were stored at $-80^{\circ} \mathrm{C}$ in a cryoprotectant solution of $10 \%$ glycerol and were preserved in the collection of the International Cooperative Biodiversity Group (ICBG) at the University of Panama. The identification of endophytic fungi was carried out as described previously [20]. Briefly, the total genomic DNA of each strain was isolated from fresh mycelium following U'Ren et al. [52]. Polymerase chain reaction (PCR) was used to amplify the nuclear ribosomal internal transcribed spacers and 5.8s gene (ITS rDNA; ca. $600 \mathrm{bp}$ ), and the first ca. $600 \mathrm{bp}$ was sequenced bidirectionally [52]. The entire sequences for each strain were compared to the nucleotide database of the National Center for Biotechnology Information (NCBI) using the Basic Local Alignment Search Tools (BLAST ${ }^{\circledR}$ ) Website.

\subsection{Media Preparation and Cultivation of Fungal Strains}

Strains Hd08 and Hd18 were reactivated aseptically on Petri dishes containing potato dextrose agar (PDA; Difco ${ }^{\mathrm{TM}}$, Becton, Dickinson and Co., Sparks, MD, USA) and incubated at $26^{\circ} \mathrm{C}$ for seven days. Then, the mycelium was removed using a sterile spatula and was placed in sterile water to obtain a homogeneous solution. This solution was poured on the surface of Petri dishes $(145 \times 90 \mathrm{~mm})$ containing MEA for all of the experimental conditions. After 15 days of incubation, the material was extracted, and the amount of crude organic extract was measured. Sterile controls were established for all of the experiments.

Chemicals as elicitors. MEA was prepared as indicated on the label; the resulting $\mathrm{pH}$ was measured using a $\mathrm{pH}$ meter (Thomas Scientific, Swedesboro, NJ, USA). The medium was then sterilized at $121^{\circ} \mathrm{C}$. When it had cooled to $45^{\circ} \mathrm{C}$, each of the elicitors was added, mixed well, and poured on Petri dishes $(145 \times 90 \mathrm{~mm})$, and the strains then were inoculated and incubated at $26^{\circ} \mathrm{C}$ for 15 days.

$\mathrm{pH}$ as an elicitor. MEA was prepared as described above and buffered with a $50 \mathrm{mmol} / \mathrm{L}$ tri-sodium citrate dihydrate solution to set values of 4.0, 4.6, and 5.6. The chemical elicitors were $\mathrm{CaCl}_{2}$ and $\mathrm{CuSO}_{4}$. The strains then were inoculated, and the plates were incubated at $26^{\circ} \mathrm{C}$ for 15 days.

Incubation temperature as an elicitor. MEA was prepared and buffered at $\mathrm{pH}=4.0$ by adding $\mathrm{CaCl}_{2}$ or $\mathrm{CuSO}_{4}$, as described above. The incubation temperatures were set at 24,28 , and $30 \pm 2{ }^{\circ} \mathrm{C}$ in the incubation chamber (Sheldon Manufacturing, Inc., Cornelius, OR, USA) for 15 days.

\subsection{Extraction and Sample Preparation}

In all of the experiments, after the incubation time, the mycelium was cut into small pieces and placed into a $1 \mathrm{~L}$ beaker and $500 \mathrm{~mL}$ of ethyl acetate was added. After $30 \mathrm{~min}$, the mixture was triturated and homogenized using a Polytron ${ }^{\circledR}$ (Brinkmann Instruments, Westbury, NJ, USA) and subsequently filtered through filter paper (Whatman No. 7) using a vacuum. The organic solvent was evaporated under a vacuum at $30^{\circ} \mathrm{C}$ using a rotary evaporator. The resulting crude extract was re-dissolved in acetone and transferred to scintillation vials, which were previously labeled and weighed, and then evaporated on a Speed Vac ${ }^{\circledR}$ Plus (Thermo Savant ${ }^{\mathrm{TM}}$, Thermo Fisher Scientific, Waltham, MA, USA) for $24 \mathrm{~h}$. Thereafter, the amount of extract was determined.

\subsection{Antibacterial Activity}

Tested microorganisms: Among the microorganisms used for the antimicrobial test, eight strains (Bacillus cereus CECT 5050, Escherichia coli CECT 433, Kocuria rhizophila CECT 241, Legionella pneumophila 
CECT 7109, Listeria monocytogenes CECT 935, Pasteurella multocida CECT 962, Salmonella enterica CECT 7161, Salmonela enterica CECT 7160, and Shigella flexneri CECT 4804) were acquired from the Spanish Types Culture Collection of the University of Valencia, Spain, and eight strains (Enterobacter cloacae ATCC 13047, Enterococcus faecalis ATCC 19433, Klebsiella pneumonia ATCC 13883, Klebsiella pneumonia ozaenae ATCC 11296, Proteus vulgaris ATCC 9484, Pseudomonas aeruginosa ATCC 10145, Staphylococcus aureus ATCC 25923, and Streptococcus oralis ATCC 35037) were acquired from the American Type Culture Collection.

In vitro bacterial growth inhibition: The antibacterial activity of each extract was determined through the susceptibility test of the British Society for Antimicrobial Chemotherapy (BSAC) [53]. The turbidity standard ( $0.5 \mathrm{McF}$ arland Turbidity Standard) was a $\mathrm{BaCl}_{2}$ solution which absorbance $(0.08-0.10$ at $625 \mathrm{~nm})$ was verified in a spectrophotometer (Spectronic 21, Bausch \& Lomb, Rochester, NY, USA). The solution was stored in the dark at $24 \pm 2{ }^{\circ} \mathrm{C}$. The bacterial inoculum of the seventeen pathogenic strains were prepared in Trypticase-Soy Agar (TSA; Bacto ${ }^{\mathrm{TM}}$, Becton, Dickinson and Co., Sparks, MD, USA) for $24 \mathrm{~h}$. Thereafter, five colonies were picked up and transferred into a tube containing a saline and isotonic solution, then visually compared to the turbidity standardas previously reported [54].

Evaluation of the minimal inhibitory concentration (MIC): A broth dilution susceptibility testing method was applied for the determination of the (MIC) [55], using a stock solution prepared by adding $15 \mathrm{mg}$ of the organic extract in $3 \mathrm{~mL}$ of Trypticase-Soy Broth (TSB). Serial dilutions of the organic extract $(3.33 \mu \mathrm{g} / \mathrm{mL}, 1.67 \mu \mathrm{g} / \mathrm{mL}, 0.56 \mu \mathrm{g} / \mathrm{mL}, 0.18 \mu \mathrm{g} / \mathrm{mL}, 0.061 \mu \mathrm{g} / \mathrm{mL}, 0.0021 \mu \mathrm{g} / \mathrm{mL}$, and $0.007 \mu \mathrm{g} / \mathrm{mL})$ and positive control (gentamycin sulfate: $104.5 \mu \mathrm{g} / \mathrm{mL}, 35.0 \mu \mathrm{g} / \mathrm{mL}, 11.6 \mu \mathrm{g} / \mathrm{mL}$, and $3.87 \mu \mathrm{g} / \mathrm{mL}$ ) were performed. Each solution was inoculated with $50 \mu \mathrm{L}$ (0.5 McFarland) of a culture of Pseudomonas aeruginosa and incubated at $37^{\circ} \mathrm{C}$ for $18 \mathrm{~h}$. The negative control was DMSO. A sterile culture media control was also used. Each assay was performed in duplicate.

\subsection{Analysis of Organic Extracts by LC-MS}

LC-MS analysis was carried out in an Agilent 1290 Infinity LC System (Agilent Technologies, Santa Clara, CA, USA) using a Zorbax ${ }^{\circledR}$ Eclipse Plus $(1.8 \mu \mathrm{m}) \mathrm{C}_{18}$ reverse phase LC column, $100 \times 3 \mathrm{~mm}$ (Agilent Technologies, Santa Clara, CA, USA). The mass spectrometer was a micrOTOF-QIII (Bruker Daltonics, Billerica, MA, USA) supplied with an electrospray ionization (ESI) source. For the positive mode Electrospray Ionization-Quadrupole-Time of Flight-Mass Spectrometry (ESI+-Q-TOF-MS) analysis, extracts were re-dissolved in methanol and filtered through a $0.45 \mu \mathrm{m}$ cellulose acetate membrane filter. Solutions of $0.5 \mu \mathrm{g} / \mathrm{mL}$ were prepared, and aliquots of $10 \mu \mathrm{L}$ were injected. The chromatographic analysis was carried out using a 37 min step gradient (UHPLC) run using mixtures of methanol and acidified water $\left(99.9 \% \mathrm{H}_{2} \mathrm{O}-0.1 \% \mathrm{FA}\right)$ as mobile phase, starting from: (a) $5-95 \% \mathrm{MeOH}-\mathrm{H}_{2} \mathrm{O}$ for $2 \mathrm{~min}$; (b) a 25 min gradient from $5: 95$ methanol: $\mathrm{H}_{2} \mathrm{O}$ to $100 \%$ methanol; (c) $100 \%$ methanol for $8 \mathrm{~min}$. The column was returned to the initial condition for $2 \mathrm{~min}$. Prior to collecting the data, two level of calibration were employed; before the analysis, an external calibration was performed using an Agilent ESI-L Low-Calibration Tuning Mix, and during the evaluation of each sample, we used hexakis $\left(1 \mathrm{H}, 1 \mathrm{H}, 2 \mathrm{H}\right.$-difluoroethoxy)-phosphazene $\left(\mathrm{m} / \mathrm{z} 622.0290[\mathrm{M}+\mathrm{H}]^{+}\right.$; Synquest Laboratories, Alachua, FL, USA) as an internal reference, for the lock mass calibration.

\section{Results}

\subsection{Culture Conditions}

The results obtained from evaluating the changes in culture conditions are listed in Table S1. The addition of chemical elicitors impacted the amount of crude extract obtained. In P. mangiferae, the best result was achieved in presence of $\mathrm{Fe}^{2+}$ and $\mathrm{Ca}^{2+}$ ion (man-3, $256.0 \mathrm{mg}$ and man-4, $232.0 \mathrm{mg}$ ); in P. microspora, under the presence of $\mathrm{Cu}^{2+}$ and $\mathrm{Ca}^{2+}$ ions (mic-4, $297.0 \mathrm{mg}$ and mic-5, 329.0 mg). 
Low $\mathrm{pH}$ values increased the amount of crude extract obtained. For both species, the best results were obtained at $\mathrm{pH}=4.0$ and $\mathrm{Cu}^{2+}$ as elicitor: in P. mangiferae (man-9, $264.3 \mathrm{mg}$ ); in P. microspora (mic-9, $260.0 \mathrm{mg})$.

The third factor to consider was the incubation temperature. Maintaining constant the $\mathrm{pH}$ at 4.0, we found that the highest amount of extract in P. mangiferae was at $30{ }^{\circ} \mathrm{C}$ for both elicitors (man-14, $528.0 \mathrm{mg}$; man-17 $448.0 \mathrm{mg}$ ); the production of extract using $\mathrm{Ca}^{2+}$ was 34-fold higher and 1.7-fold higher using $\mathrm{Cu}^{2+}$ compared to the amounts obtained in phase II. For P. microspora, the highest amount of extract was obtained at $24{ }^{\circ} \mathrm{C}$ using $\mathrm{Cu}^{2+}$ as elicitor (mic-15, $1194.0 \mathrm{mg}$ ) that was 4.6-fold higher that the obtained amount in phase II.

\subsection{Antibacterial Activity}

A total of 34 extracts were assayed against a panel of pathogenic bacteria in a preliminary antibacterial test (disc diffusion method, $\mathrm{mm}$ ), and only 11 extracts showed growth inhibition: seven from P. mangiferae and four from P. microspora (Table 1). These extracts were capable of inhibiting the growth of 13 of 17 pathogenic bacterial strains. Larger inhibition zones were observed against $P$. aeruginosa $(12.5 \mathrm{~mm})$ and L. monocytogenes $(11.0 \mathrm{~mm})$. Extract man- 6 displayed the highest broad-spectrum of antimicrobial activity (inhibited seven pathogenic strains), followed by extracts man-9 and mic-9 (both inhibited six pathogenic strains). Nevertheless, the culture condition for man-6 $\left(\mathrm{CaCl}_{2}, \mathrm{pH}=4.0\right.$ and $\left.\mathrm{T}=26^{\circ} \mathrm{C}\right)$ induced one of the lowest amounts of organic extract $(15.4 \mathrm{mg})$. The culture condition for extracts man-9 and mic-9 $\left(\mathrm{CuSO}_{4}, \mathrm{pH}=4.0, \mathrm{~T}=26^{\circ} \mathrm{C}\right)$ were more favorable.

Extracts man-15 and mic-11 exhibited selectivity against $P$. aeruginosa, the most sensitive strain. To determine the MIC using P. aeruginosa, five of the eleven extracts were selected. In this experiment, only extracts man-6 $(0.11 \mu \mathrm{g} / \mathrm{mL})$ and mic-9 $(0.56 \mu \mathrm{g} / \mathrm{mL})$ demonstrated growth inhibition.

Hence, to correlate the chemical profile with the antibacterial activity against $P$. aeruginosa, three samples were selected from $P$. mangiferae to be analyzed by LC-MS: (1) one active, man-7; (2) one with broad-spectrum activity, man-9 (12.5 mm inhibition zone); and (3) one with selective activity, man-15 (9.5 mm inhibition zone).

To our knowledge, there are only two reports of secondary metabolites from P. mangiferae $[20,56]$.

\subsection{Evaluation of the Chemical Diversity}

Table 2 lists the principal molecular ions present in the analyzed extracts and their determined molecular formulas. Extracts man-7 and man-15 showed a similar chemical composition; nevertheless, at least four compounds were only present in extract man-15. The molecular ions are linked, mainly to polyoxygenate compounds, but some nitrogenous are present too. In all three extracts (man-7, man-9, man-15), the presence of mangiferaelactone was determined (retention time $t_{\mathrm{R}} 21.55-21.59 \mathrm{~min} ; \mathrm{m} / \mathrm{z}$ 401.2017 $[\mathrm{M}+\mathrm{H}]^{+}$); none of the other previously isolated compounds from P. mangiferae was detected as principal components of the analyzed samples (see Figure S1). The pseudo molecular ion $\mathrm{m} / \mathrm{z}$ $338.341[\mathrm{M}+\mathrm{H}]^{+}$, which appeared at $t_{R} 28.3 \mathrm{~min}$, has been established as a possible molecular formula (calculated for $\mathrm{C}_{22} \mathrm{H}_{44} \mathrm{NO}$ ). This compound appeared in the chromatograms of extracts man-9 and man-15, but it was absent in the man-7 extract (Figure 1, Table 2), suggesting that it could be responsible for the antibacterial activity against $P$. aeruginosa. 
Table 1. Antibacterial activity in the disk diffusion test ${ }^{1}$ of organic extracts produced by Pestalotiopsis spp.

\begin{tabular}{|c|c|c|c|c|c|c|c|c|c|c|c|c|c|c|c|}
\hline Fungi & Extract & $\begin{array}{c}i \overline{8} \\
\dot{8}\end{array}$ & 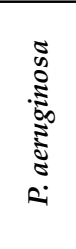 & 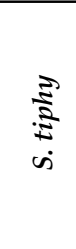 & 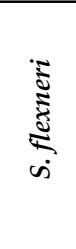 & 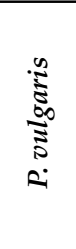 & 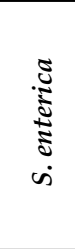 & 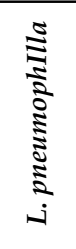 & $\frac{\infty}{\tilde{\Xi}}$ & 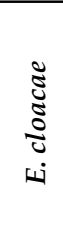 & 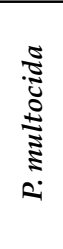 & 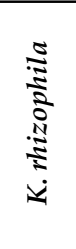 & 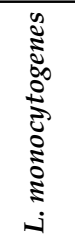 & 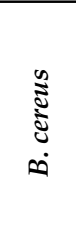 & 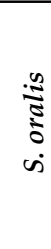 \\
\hline \multirow{7}{*}{ P. mangiferae } & man-1 & & & & & & & & & & & & 8.5 & & 9.5 \\
\hline & man-2 & & 8.5 & & & 8.5 & & & & & & & 8.0 & & \\
\hline & man-3 & & 8.5 & & 7.5 & & & & 9.0 & 9.0 & & & 7.5 & & \\
\hline & man-6 & & 10.0 & 8.5 & 9.0 & & 9.0 & & & & 8.0 & & 11.0 & 8.0 & \\
\hline & man-7 & & & & & & & 8.0 & 8.5 & 8.5 & & 9.0 & & & 7.5 \\
\hline & man-9 & & 12.5 & & & 8.5 & & 8.5 & 8.0 & & & 7.5 & 7.5 & & \\
\hline & man-15 & & 9.5 & & & & & & & & & & & & \\
\hline \multirow{4}{*}{ P. microspora } & mic-9 & & 8.0 & 8.5 & & 7.5 & & & & & & 8.0 & 7.5 & 8.5 & \\
\hline & mic-10 & 8.0 & & & & & & & & & & 8.5 & 8.5 & & \\
\hline & mic-11 & & 9.5 & & & & & & & & & & & & \\
\hline & mic-12 & & 9.5 & & & 7.5 & & & & & & & & 7.5 & \\
\hline $\begin{array}{l}\text { Positive } \\
\text { control }\end{array}$ & $\begin{array}{c}\text { Gentamycin } \\
\text { sulfate } \\
(10 \mu \mathrm{g} / \mathrm{mL})\end{array}$ & 18.5 & 17.5 & 14.5 & 13.5 & 13.0 & 13.0 & 12.0 & 10.0 & 9.5 & 9.5 & 30.0 & 18.0 & 17.0 & 9.0 \\
\hline
\end{tabular}

${ }^{1}$ Results are given in mm of inhibition. 
Table 2. Molecular ions of secondary metabolites present in extracts obtained from P. mangiferae.

\begin{tabular}{|c|c|c|c|c|c|c|}
\hline Retention Time ${ }^{1}\left(t_{R}\right)$ & $m / z$ & {$[\mathbf{M}+\mathbf{H}]^{+}$} & {$[\mathrm{M}+\mathrm{Na}]^{+}$} & Dimers & Molecular Formula & Extracts \\
\hline $19.44-19.50$ & 588.36567 & 589.369 & & $1177.720[2 \mathrm{M}+\mathrm{H}]^{+}$ & $\mathrm{C}_{34} \mathrm{H}_{52} \mathrm{O}_{8}$ & man-7, man-15 \\
\hline $20.14-20.37$ & 278.18765 & 279.194 & & & $\mathrm{C}_{17} \mathrm{H}_{26} \mathrm{O}_{3}$ & man-7 \\
\hline $20.78-20.87$ & 588.36567 & 589.369 & & $1177.720[2 \mathrm{M}+\mathrm{H}]^{+}$ & $\mathrm{C}_{34} \mathrm{H}_{52} \mathrm{O}_{8}$ & man-7, man-15 \\
\hline \multirow{2}{*}{$21.55-21.59$} & 282.18524 & 283.193 & & $565.375[2 \mathrm{M}+\mathrm{H}]^{+}$ & $\mathrm{C}_{16} \mathrm{H}_{26} \mathrm{O}_{4}$ & man-7, man-9, man-15 \\
\hline & 400.20917 & 401.217 & 423.199 & $\begin{array}{c}801.424[2 \mathrm{M}+\mathrm{H}]^{+} \\
823.407[2 \mathrm{M}+\mathrm{Na}]^{+}\end{array}$ & $\mathrm{C}_{20} \mathrm{H}_{32} \mathrm{O}_{8}$ & man-7, man-9, man-15 \\
\hline \multirow{4}{*}{$22.39-22.43$} & 394.28663 & 395.295 & & \multirow{4}{*}{$\begin{array}{c}995.716 \\
{\left[2 \mathrm{M}+\mathrm{H}_{2} \mathrm{O}+\mathrm{H}\right]^{+}}\end{array}$} & $\mathrm{C}_{27} \mathrm{H}_{38} \mathrm{O}_{2}$ & man-7, man-15 \\
\hline & 412.29317 & 413.303 & & & $\mathrm{C}_{22} \mathrm{H}_{40} \mathrm{~N}_{2} \mathrm{O}_{5}$ & man-7, man-15 \\
\hline & 470.33906 & 471.347 & & & $\mathrm{C}_{30} \mathrm{H}_{46} \mathrm{O}_{4}$ & man-7, man-15 \\
\hline & 488.34560 & 489.354 & & & $\mathrm{C}_{30} \mathrm{H}_{48} \mathrm{O}_{5}$ & man-7, man-15 \\
\hline $23.40-23.45$ & 314.24516 & 315.256 & 337.236 & & $\mathrm{C}_{38} \mathrm{H}_{34} \mathrm{O}_{4}$ & man-15 \\
\hline \multirow[b]{2}{*}{$23.72-23.81$} & 428.30737 & & 451.298 & & $\mathrm{C}_{31} \mathrm{H}_{40} \mathrm{O}$ & man-7, man-15 \\
\hline & 428.31324 & 429.320 & & & $\mathrm{C}_{24} \mathrm{H}_{44} \mathrm{O}_{6}$ & man-15 \\
\hline 24.54 & 278.22403 & 279.231 & 301.211 & $557.446[2 \mathrm{M}+\mathrm{H}]^{+}$ & $\mathrm{C}_{18} \mathrm{H}_{30} \mathrm{O}_{2}$ & man-7, man-15 \\
\hline 24.60 & 452.31324 & & 475.304 & $927.610[2 \mathrm{M}+\mathrm{Na}]^{+}$ & $\mathrm{C}_{26} \mathrm{H}_{44} \mathrm{O}_{6}$ & man-15 \\
\hline 26.86 & 281.27132 & 282.279 & 304.261 & & $\mathrm{C}_{18} \mathrm{H}_{35} \mathrm{NO}$ & man-7, man-15 \\
\hline 27.52 & 283.28697 & 284.294 & 306.276 & & $\mathrm{C}_{18} \mathrm{H}_{37} \mathrm{NO}$ & man-7, man-15 \\
\hline $27.83-27.87$ & 390.27646 & 391.283 & 413.261 & $803.536[2 \mathrm{M}+\mathrm{Na}]^{+}$ & $\mathrm{C}_{24} \mathrm{H}_{38} \mathrm{O}_{4}$ & man-7, man-9, man-15 \\
\hline 28-33 & 337.33392 & 338.341 & 360.320 & $675.670[2 \mathrm{M}+\mathrm{H}]^{+}$ & $\mathrm{C}_{22} \mathrm{H}_{43} \mathrm{NO}$ & man-9, man-15 \\
\hline 28.40 & 418.28663 & 419.308 & 441.288 & $859.578[2 \mathrm{M}+\mathrm{Na}]^{+}$ & $\mathrm{C}_{29} \mathrm{H}_{38} \mathrm{O}_{2}$ & man-7 \\
\hline \multirow{2}{*}{$31.25-31.36$} & 662.43884 & 663.444 & 685.40 & & $\mathrm{C}_{40} \mathrm{H}_{36} \mathrm{NO}_{4}$ & man-7, man-9, man-15 \\
\hline & 721.51233 & 722.519 & & & $\mathrm{C}_{41} \mathrm{H}_{71} \mathrm{NO}_{9}$ & man-15 \\
\hline
\end{tabular}

${ }^{1}$ Time is given in minutes. 


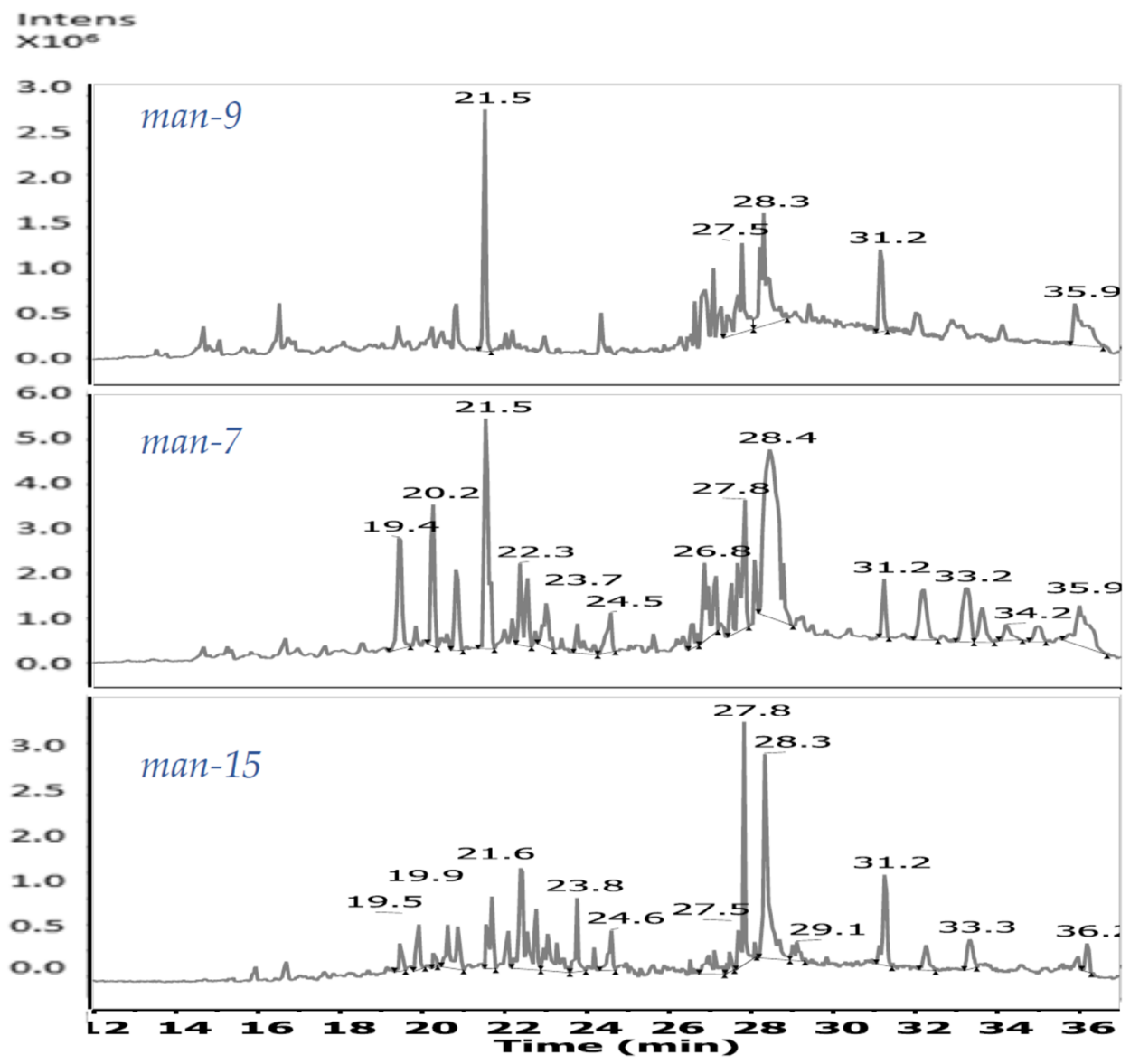

Figure 1. Total ion chromatograms (TICs) of extracts man-9, man-7, and man-15.

Chemical diversity of the three extracts from P. mangiferae (man-7, man-9, and man-15) was analyzed by LC-ESI-Q-TOF-MS. The total ion chromatograms for each sample are presented in Figure 1. The peak at $t_{\mathrm{R}} 21.5 \mathrm{~min}$ is common to all three analyzed samples. The MS spectrum of this peak showed ions $[\mathrm{M}+\mathrm{H}]^{+}$and $[\mathrm{M}+\mathrm{Na}]^{+}$at $m / z 401.217$ and 423.199 , respectively. Additionally, two ion clusters were detected: $\mathrm{M}_{2} \mathrm{H}^{+}$and $\mathrm{M}_{2} \mathrm{Na}^{+}$at $m / z 801.424$ and 823.407, respectively (Figure 2A), which matched the MS data for mangiferaelactone, a previously characterized compound. This compound had a relatively lower concentration in sample man-15. Based on its selectivity against $P$. aeruginosa (9.5 mm inhibition zone), this compound could be proposed as the major component of the extract, for example, the peak at $t_{\mathrm{R}} 27.8 \mathrm{~min}$ with $[\mathrm{M}+\mathrm{H}]^{+},[\mathrm{M}+\mathrm{Na}]^{+}$, and $[2 \mathrm{M}+\mathrm{Na}]^{+}$ions at $\mathrm{m} / \mathrm{z} 391.283$, 413.261, and 803.536, respectively (Figure 2D). The polar section of man-15 was the most complex, indicating a higher level of chemical diversity then man-7 and man-9.

Extract man-7 showed a higher relative concentration among the components of the polar section (peaks at $t_{\mathrm{R}} 19.4,20.2,20.7$, and $21.5 \mathrm{~min}$ ). Its moderate polarity section included a peak at $t_{\mathrm{R}} 28.4 \mathrm{~min}$ with $[\mathrm{M}+\mathrm{H}]^{+},[\mathrm{M}+\mathrm{Na}]^{+}$, and $[2 \mathrm{M}+\mathrm{Na}]^{+}$ions at $\mathrm{m} / \mathrm{z} 419.308,441.276$, and 859.579, respectively (Figure 2B), compared with extracts man-9 and man-15 that had a peak at $t_{\mathrm{R}} 28.3$ min with $[\mathrm{M}+\mathrm{H}]^{+}$, $[\mathrm{M}+\mathrm{Na}]^{+}$, and $[2 \mathrm{M}+\mathrm{H}]^{+}$ions at $\mathrm{m} / \mathrm{z} 338.337,360.319$, and 675.670 , respectively (Figure $2 \mathrm{C}$ ). 

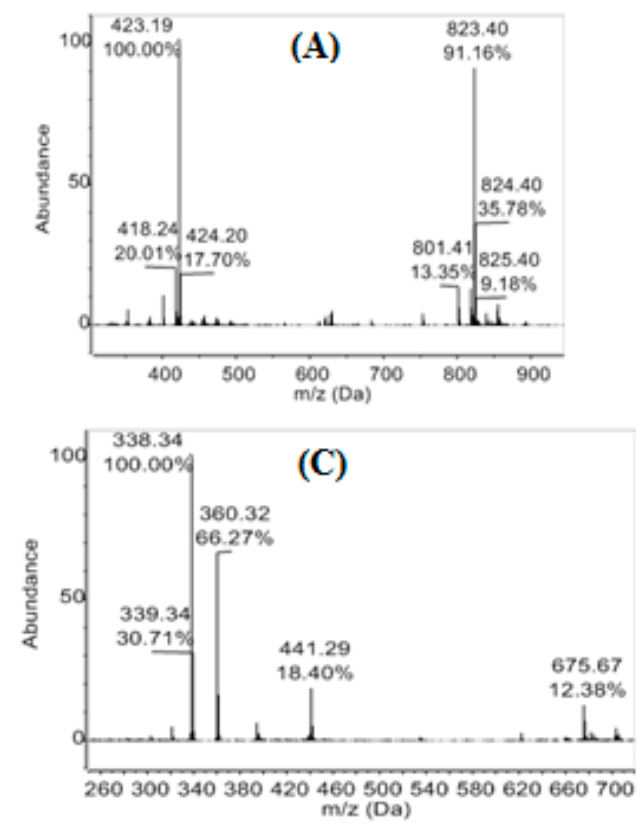
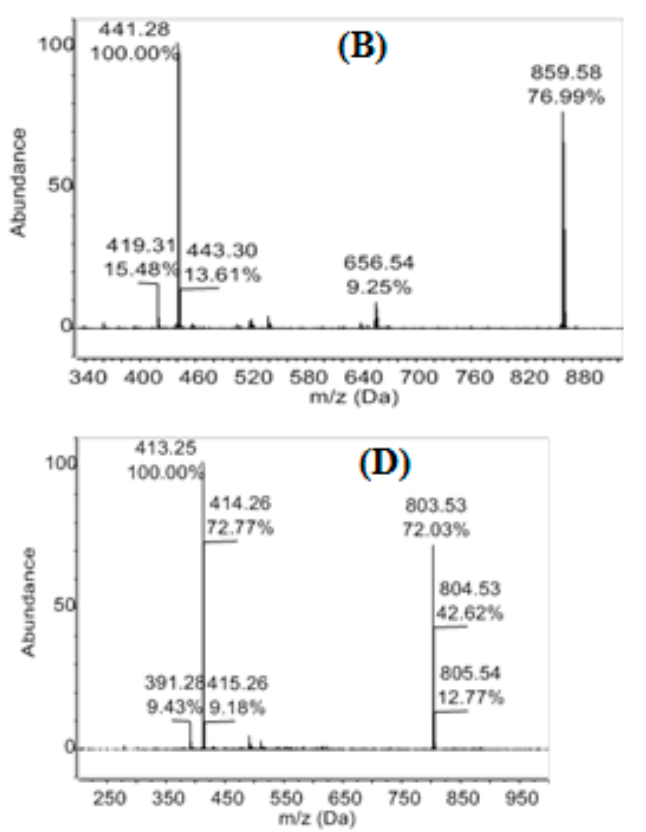

Figure 2. Mass spectra of selected peaks. (A) Mangiferaelactone at $t_{\mathrm{R}} 21.5 \mathrm{~min}$ in extracts man-7, man-9, and man-15. (B) Peak in extract man-7 at $t_{\mathrm{R}} 28.4 \mathrm{~min}$. (C) Peak in extracts man-9 and man-15 at $t_{\mathrm{R}}$ 28.3 min. (D) Peak in extracts man-7 and man-15 at $t_{\mathrm{R}} 27.8 \mathrm{~min}$.

\section{Discussion}

As we mentioned above, there are only two reports related to the isolation and characterization of secondary metabolites from P. mangiferae; early culturing under two different conditions produced antibacterial compounds mangiferaelactone (1) and 4-(2,4,7-trioxa-bicyclo[4.1.0]heptan-3-yl) phenol (see Figure S1) [20,56]. Neither one was among the main components present in the extracts analyzed here by high resolution LC-MS, nor the other compounds with a low molecular weight.

Our results showed that in this initial study, Pestalotiopsis showed prolific antibacterial activity. The results of Table 2 indicate that each extract had a different biological activity profile. This means that the chemical composition changes in diversity and concentration.

The changes in the culture conditions played a role in differences in the chemical diversity of P. mangiferae and the genus Pestalotiopsis. This was confirmed by the wide range of the preliminary antibacterial activities determined for each of the extracts and through the LC-HRMS analysis of the three extracts. According to the revised reviews and recent publications (Table S2) on the secondary metabolites isolated from the genus Pestalotiopsis and the antibacterial activity previously determined, most of the molecular formulas for the metabolites reported here did not match with those reported earlier for the genus. Nonetheless, taking into account the previously isolated compounds from the genus Pestalotiopsis or from P. mangiferae and the molecular formula obtained through high-resolution mass spectrometry, we proposed some molecular structures; also, in most of the cases they are related with a previously isolated compound with antibacterial or antifungal activity.

Five major reviews on the chemistry and bioactivity of the genus Pestalotiopsis were published until 2017 [14-18]. An exhaustive exploration of the available compounds' structures allowed us to establish that the majority of the compounds present in the analyzed extracts of $P$. mangiferae have not been isolated from a species of the genus Pestalotiopsis. Nevertheless, it could be proposed that they belong to three of the main classes of compounds isolated from the genus, namely: (a) polyketides/polyols derivatives; (b) terpenoids/triterpenoids; and (c) nitrogen-containing compounds.

The major group of compounds present in the analyzed extracts could belong to polyketide/polyol derivatives. For example, we proposed the hydrolysis of mangiferaelactone (1) $\left(\mathrm{C}_{20} \mathrm{H}_{32} \mathrm{O}_{8}\right)$ that will result in the hypothetical trihydroxylactone (1a) (not-yet-detected by MS-analysis), its successive 
dehydration and methylation could lead to two lactones (1b) $\left(\mathrm{C}_{16} \mathrm{H}_{26} \mathrm{O}_{4}\right)$ and (1d) $\left(\mathrm{C}_{17} \mathrm{H}_{26} \mathrm{O}_{3}\right)$, respectively (Figure 3). Compound (1) has the same molecular formula as koninginins $\mathrm{B}\left(\mathbf{1} \mathbf{e} ; \mathrm{C}_{16} \mathrm{H}_{26} \mathrm{O}_{4}\right)$ and $\mathrm{E}\left(\mathbf{1 f} ; \mathrm{C}_{16} \mathrm{H}_{26} \mathrm{O}_{4}\right)$ isolated from the genus Trichoderma [57-59], and they probably have the same precursor as compound (1a) $\left(\mathrm{C}_{16} \mathrm{H}_{28} \mathrm{O}_{5}\right)$.

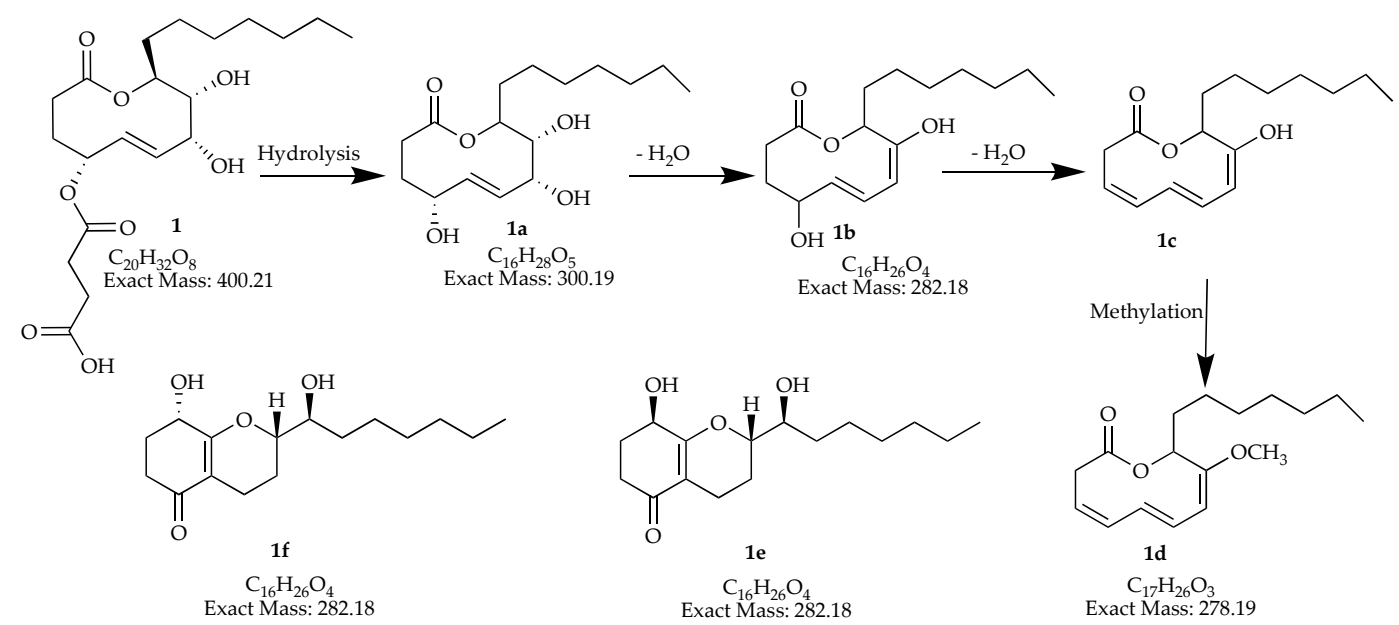

Figure 3. Proposed polyketide/polyol derivatives $\mathbf{1 b}$,d that could be present in extracts man-7, man-9, and man-15, having as a precursor compound $\mathbf{1}$ and the intermediates $\mathbf{1 a}, \mathbf{c}$. Polyketides $\mathbf{1 e , f}$ previously isolated from the genus Trichoderma with same molecular formula as $\mathbf{1} \mathbf{b}$.

Two molecular formulas could correspond to triterpenoids $\left(\mathrm{C}_{30} \mathrm{H}_{46} \mathrm{O}_{4} / \mathrm{C}_{30} \mathrm{H}_{48} \mathrm{O}_{5}\right)$. From the genus Pestalotiopsis, only oleanane- and ursane-type triterpenes have been isolated $[14,17,60]$. Ursane-type triterpenes have been reported when to the culture medium was added ursolic acid [61]. Nevertheless, oleanane-type were isolated (15 $\alpha)$-15- hydroxysoyasapogenol B (2), $(7 \beta, 15 \alpha)-7$, 15-dihydroxysoyasapogenol B (3) and (7 3$)-7,29$-dihydroxysoyasapogenol B (4) from Pestalotiopsis clavispora [60], together with ursolic acid. These three compounds (2-4) could be synthesized by biological oxidation mechanism derived in one of the triterpenoids $\mathbf{2} \mathbf{a}, \mathbf{3} \mathbf{a}$ or $\mathbf{4 a}$, respectively; they have the molecular formula $\mathrm{C}_{30} \mathrm{H}_{46} \mathrm{O}_{4}$ or $\mathrm{C}_{30} \mathrm{H}_{48} \mathrm{O}_{5}$ established by high resolution MS in extracts man-7 and man-15 (Figure 4).

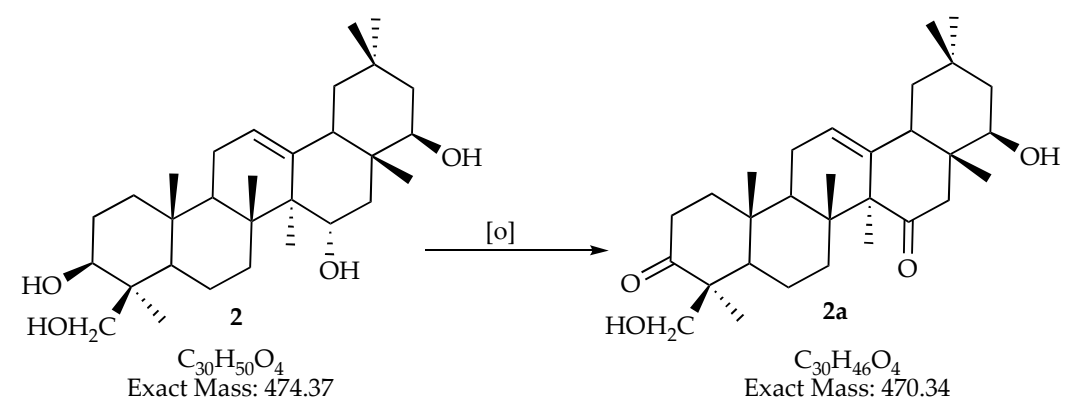

Figure 4. Cont. 


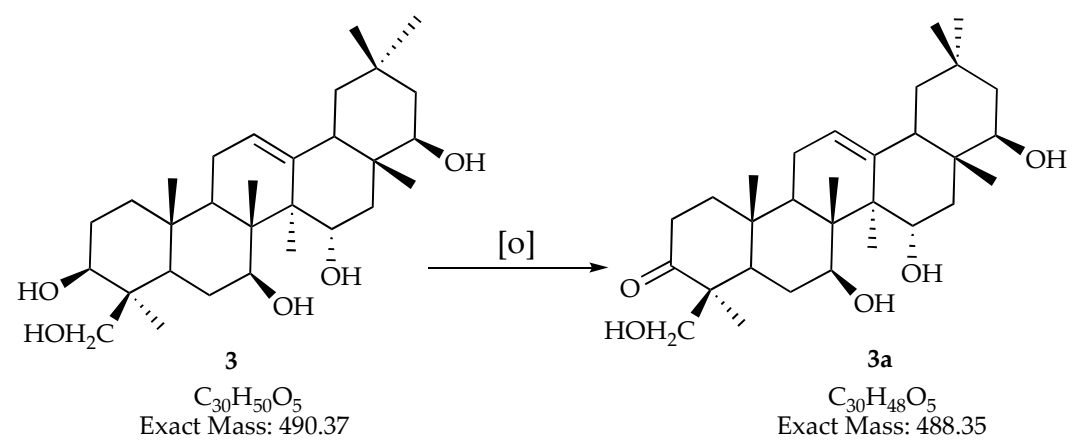

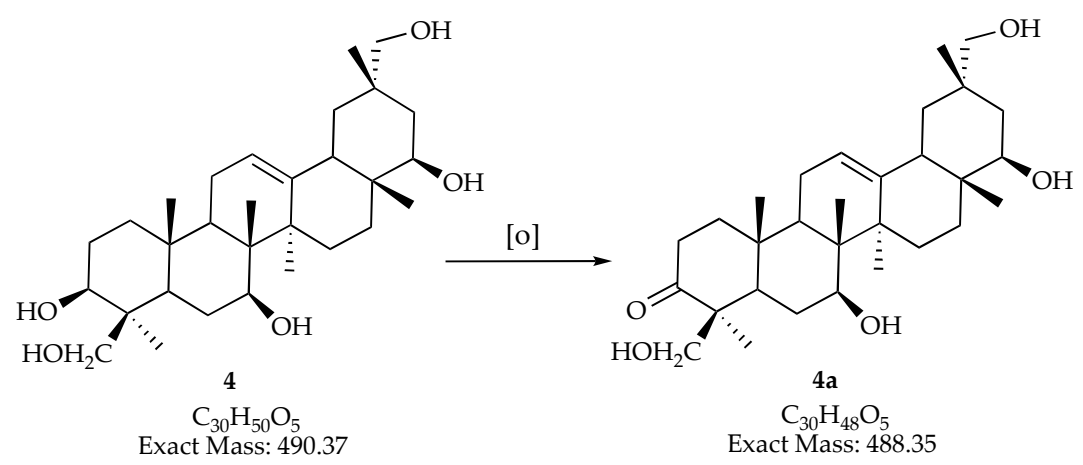

Figure 4. Proposed structure for compounds 2a, 3a, and $4 \mathbf{a}$ based on the molecular formula determined by HRMS in extracts man-7 and man-15 and their proposed biosynthetic precursor.

In our results two molecular ions have the same molecular formula $\mathrm{C}_{34} \mathrm{H}_{52} \mathrm{O}_{8}$, but they eluted at different time and are both present in extracts man-7 and man-15. These isomers could be related to fusapirone $\left(5 ; \mathrm{C}_{34} \mathrm{H}_{54} \mathrm{O}_{9}\right)$ a compound with antifungal activity, previously, isolated from Fusarium semitectum [62], it possess multiple chiral centers and can derived into compound $\left(5 \mathbf{a} ; \mathrm{C}_{34} \mathrm{H}_{52} \mathrm{O}_{8}\right)$ by dehydration (Figure 5).

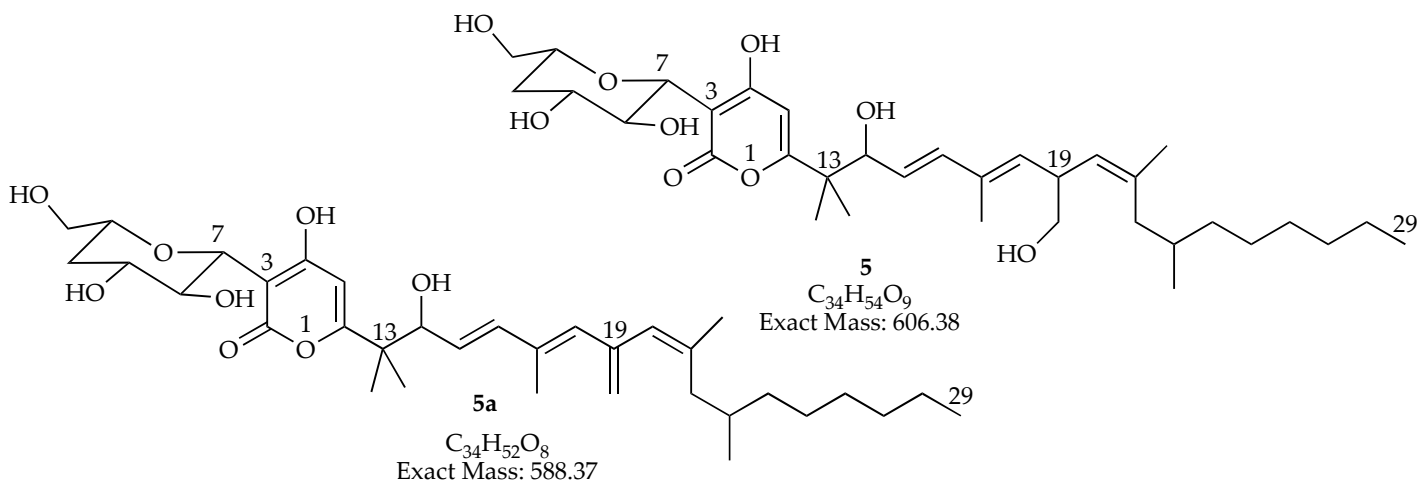

Figure 5. Dehydration of the polyketide derivative fusapirone 5 could produce compound $\mathbf{5 a}$ with a molecular formula $\mathrm{C}_{34} \mathrm{H}_{57} \mathrm{O}_{8}$, determined in extracts man-7 and man-15.

The dehydrogenation of asperacine $\left(\mathbf{6} ; \mathrm{C}_{40} \mathrm{H}_{36} \mathrm{~N}_{6} \mathrm{O}_{4}\right)$ results in compound $\mathbf{6 a}\left(\mathrm{C}_{40} \mathrm{H}_{36} \mathrm{~N}_{6} \mathrm{O}_{4}\right)$ with an imine function (Figure 6), this molecular formula was determined for extracts man-7, man-9, and man-15. 

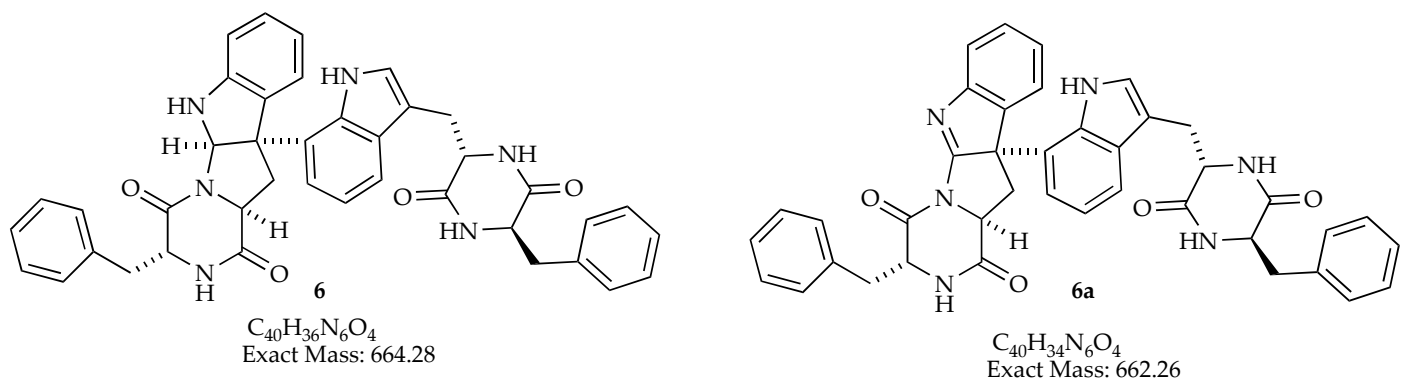

Figure 6. Nitrogen derivative 6a, that could be present in extracts man-7, man-9, and man-15.

\section{Conclusions}

For this study were selected two strains of Pestalotiopsis endophytic fungi (P. microspora Hd18 and P. mangiferae), that are capable of producing secondary metabolites with relevant biological activities. The strategy developed in this work included variations of the culture conditions, the determination of the antibacterial activity of the obtained extracts, together with the effective analysis of the chemical profile using LC-HRMS. This strategy could improve the discovery of new molecules with a pharmaceutical potential, in this case antibacterial. Hence, this work confirmed changes in the chemical diversity and biological activity of P. microspora Hd18 and, principally, P. mangiferae Hd08 under varying the culture conditions.

Taking into account the chemical diversity and the preliminary antibacterial activity displayed by P. mangiferae, further work will need to establish and confirm the chemical composition of each extract as well as the antibacterial activity of a single compound.

Supplementary Materials: The following are available online at http://www.mdpi.com/2309-608X/6/3/140/s1, Figure S1: Structure of compounds previously isolated from P. mangiferae. Table S1: Culture parameters and amount of organic extract produced by Pestalotiopsis spp., Table S2: Molecular ions and formulas of compounds isolated from the genus Pestalotiopsis

Author Contributions: M.M.A.-P., R.V., and N.R. designed and performed the experiments and analyzed the data. D.T.-M. analyzed the data and reviewed, edited, and wrote the paper. L.C.-R. designed the experiments, analyzed the data, and edited and wrote the paper. All of the authors have read and agreed to the published version of the manuscript.

Funding: This work was partially supported by the National Secretariat for Science, Technology and Innovation of Panama (SENACYT, grants COL10-060 and FID11-051), the Projects of Nagoya Protocols' Application in Panama, and the National Research System of Panama (SNI).

Acknowledgments: We gratefully acknowledge the Government of Panama through the Ministerio de Ambiente (MiAMBIENTE) for granting the corresponding permits to collect the samples used in this study.

Conflicts of Interest: The authors declare no conflict of interest. The funders had no role in the design of the study; in the collection, analyses, or interpretation of data; in the writing of the manuscript; or in the decision to publish the results.

\section{References}

1. Escolà-Vergé, L.; Los-Arcos, I.; Almirante, B. New antibiotics for the treatment of infections by multidrug-resistant microorganisms. Med. Clín. (Engl. Ed.) 2020, 154, 351-357. [CrossRef]

2. Tacconelli, E.; Magrini, N. Global Priority List of Antibiotic-Resistant Bacteria to Guide Research, Discovery, and Development of New Antibiotics; World Health Organization: Geneva, Switzerland, 2017.

3. Mani Chandrika, K.V.S.; Sharma, S. Promising antifungal agents: A minireview. Bioorg. Med. Chem. 2020, 28, 115398. [CrossRef] [PubMed]

4. Outterson, K.; Rex, J.H. Evaluating for-profit public benefit corporations as an additional structure for antibiotic development and commercialization. Transl. Res. 2020, 220, 182-190. [CrossRef] [PubMed]

5. Singer, A.C.; Kirchhelle, C.; Roberts, A.P. (Inter)nationalising the antibiotic research and development pipeline. Lancet Infect. Dis. 2020, 20, e54-e62. [CrossRef] 
6. Newman, D.J.; Cragg, G.M. Natural Products as Sources of New Drugs over the Nearly Four Decades from 01/1981 to 09/2019. J. Nat. Prod. 2020, 83, 770-803. [CrossRef]

7. Newman, D.J.; Cragg, G.M. Plant Endophytes and Epiphytes: Burgeoning Sources of Known and “Unknown” Cytotoxic and Antibiotic Agents? Planta Med. 2020. [CrossRef]

8. Gupta, S.; Chaturvedi, P.; Kulkarni, M.G.; Van Staden, J. A critical review on exploiting the pharmaceutical potential of plant endophytic fungi. Biotechnol. Adv. 2020, 39, 107462. [CrossRef]

9. Hyde, K.D.; Xu, J.; Rapior, S.; Jeewon, R.; Lumyong, S.; Niego, A.G.T.; Abeywickrama, P.D.; Aluthmuhandiram, J.V.S.; Brahamanage, R.S.; Brooks, S.; et al. The amazing potential of fungi: 50 ways we can exploit fungi industrially. Fungal Divers. 2019, 97, 1-136. [CrossRef]

10. Sánchez-Fernández, R.E.; Sánchez-Ortiz, B.L.; Sandoval-Espinosa, Y.K.M.; Ulloa-Benítez, Á.; Armendáriz-Guillén, B.; García-Méndez, M.C.; Macías-Rubalcava, M.L. Hongos Endófitos: Fuente Potencial de Metabolitos Secundarios Bioactivos con Utilidad en Agricultura y Medicina. Tip Rev. Espec. Cienc. Quím. Biol. 2013, 16, 132-146. [CrossRef]

11. Pye, C.R.; Bertin, M.J.; Lokey, R.S.; Gerwick, W.H.; Linington, R.G. Retrospective analysis of natural products provides insights for future discovery trends. Proc. Natl. Acad. Sci. USA 2017, 114, 5601-5606. [CrossRef]

12. Torres-Mendoza, D.; Ortega, H.E.; Cubilla-Rios, L. Patents on Endophytic Fungi Related to Secondary Metabolites and Biotransformation Applications. J. Fungi 2020, 6, 58. [CrossRef]

13. Urones, J.G.; Marcos, I.S.; Diez, D.; Cubilla, L.R. Tricyclic diterpenes from Hyptys dilatata. Phytochemistry 1998, 48, 1035-1038. [CrossRef]

14. Yang, X.L.; Zhang, J.Z.; Luo, D.Q. The taxonomy, biology and chemistry of the fungal Pestalotiopsis genus. Nat. Prod. Rep. 2012, 29, 622-641. [CrossRef] [PubMed]

15. Wang, K.; Lei, J.; Wei, J.; Yao, N. Bioactive Natural Compounds from the Plant Endophytic Fungi Pestalotiopsis spp. Mini Rev. Med. Chem. 2012, 12, 1382-1393. [PubMed]

16. Kumar Deshmukh, S.; Prakash, V.; Ranjan, H. Recent advances in the discovery of bioactive metabolites from Pestalotiopsis. Phytochem. Rev. 2017, 16, 883-920. [CrossRef]

17. Xu, J.; Yang, X.; Lin, Q. Chemistry and biology of Pestalotiopsis-derived natural products. Fungal Divers. 2014, 66, 37-68. [CrossRef]

18. Xu, J.; Ebada, S.S.; Proksch, P. Pestalotiopsis a highly creative genus: Chemistry and bioactivity of secondary metabolites. Fungal Divers. 2010, 44, 15-31. [CrossRef]

19. Helaly, S.E.; Thongbai, B.; Stadler, M. Diversity of biologically active secondary metabolites from endophytic and saprotrophic fungi of the ascomycete order Xylariales. Nat. Prod. Rep. 2018, 35, 992-1014. [CrossRef]

20. Ortega, H.E.; Shen, Y.Y.; Tendyke, K.; Ríos, N.; Cubilla-Ríos, L. Polyhydroxylated macrolide isolated from the endophytic fungus Pestalotiopsis mangiferae. Tetrahedron Lett. 2014, 55, 2642-2645. [CrossRef]

21. Maram, L.; Das, B. The First Stereoselective Total Synthesis of Mangiferaelactone: An Antibacterial Fungal Nonanolide. Synlett 2014, 25, 2327-2330.

22. Kumar, R.; Rej, R.K.; Nanda, S. Asymmetric total synthesis of (-)-mangiferaelactone by using an appropriately substituted thiophene as a masked synthon for C-alkyl glycoside. Tetrahedron Asymmetry 2015, 26, 751-759. [CrossRef]

23. Reddy, B.V.S.; Reddy, P.S.; Babu, K.V.; Reddy, B.P.; Yadav, J.S. Stereoselective Total Synthesis of Mangiferaelactone using D-Mannose as a Chiral Pool. Helv. Chim. Acta 2015, 98, 1395-1402. [CrossRef]

24. Strobel, G.; Yang, X.; Sears, J.; Kramer, R.; Sidhu, R.S.; Hess, W.M. Taxol from Pestalotiopsis microspora, an endophytic fungus of Taxus wallachiana. Microbiology 1996, 142, 3-8. [CrossRef] [PubMed]

25. Strobel, G.; Ford, E.; Worapong, J.; Harper, J.K.; Arif, A.M.; Grant, D.M.; Fung, P.C.W.; Ming Wah Chau, R. Isopestacin, an isobenzofuranone from Pestalotiopsis microspora, possessing antifungal and antioxidant activities. Phytochemistry 2002, 60, 179-183. [CrossRef]

26. Liu, S.; Dai, H.; Makhloufi, G.; Heering, C.; Janiak, C.; Hartmann, R.; Mándi, A.; Kurtán, T.; Müller, W.E.G.; Kassack, M.U.; et al. Cytotoxic 14-Membered Macrolides from a Mangrove-Derived Endophytic Fungus, Pestalotiopsis microspora. J. Nat. Prod. 2016, 79, 2332-2340. [CrossRef]

27. Nalin Rathnayake, G.R.; Savitri Kumar, N.; Jayasinghe, L.; Araya, H.; Fujimoto, Y. Secondary Metabolites Produced by an Endophytic Fungus Pestalotiopsis microspora. Nat. Prod. Bioprospect. 2019, 9, 411-417. [CrossRef] 
28. Bertrand, S.; Bohni, N.; Schnee, S.; Schumpp, O.; Gindro, K.; Wolfender, J.-L. Metabolite induction via microorganism co-culture: A potential way to enhance chemical diversity for drug discovery. Biotechnol. Adv. 2014, 32, 1180-1204. [CrossRef]

29. Bode, H.B.; Bethe, B.; Höfs, R.; Zeeck, A. Big Effects from Small Changes: Possible Ways to Explore Nature's Chemical Diversity. Chembiochem 2002, 3, 619-627. [CrossRef]

30. Takahashi, J.A.; Campos Teles, A.P.; De Almeida Pinto Bracarense, A.; Corrêia Gomes, D. Classical and epigenetic approaches to metabolite diversification in filamentous fungi. Phytochem. Rev. 2013, 12, 773-789. [CrossRef]

31. Frey-Klett, P.; Burlinson, P.; Deveau, A.; Barret, M.; Tarkka, M.; Sarniguet, A. Bacterial-Fungal Interactions: Hyphens between Agricultural, Clinical, Environmental, and Food Microbiologists. Microbiol. Mol. Biol. Rev. 2011, 75, 583-609. [CrossRef]

32. Pettit, R.K. Mixed fermentation for natural product drug discovery. Appl. Microbiol. Biotechnol. 2009, 83, 19-25. [CrossRef]

33. Shank, E.A.; Kolter, R. New developments in microbial interspecies signaling. Curr. Opin. Microbiol. 2009, 12, 205-214. [CrossRef] [PubMed]

34. Adelin, E.; Slimani, N.; Cortial, S.; Schmitz-Alfonso, I.; Ouazzani, J. Platotex: An innovative and fully automated device for cell growth scale-up of agar-supported solid-state fermentation. J. Ind. Microbiol. Biotechnol. 2011, 38, 299-305. [CrossRef] [PubMed]

35. Kjærbølling, I.; Mortensen, U.H.; Vesth, T.; Andersen, M.R. Strategies to establish the link between biosynthetic gene clusters and secondary metabolites. Fungal Genet. Biol. 2019, 130, 107-121. [CrossRef] [PubMed]

36. Ramesha, K.P.; Mohana, N.C.; Nuthan, B.R.; Rakshith, D.; Satish, S. Epigenetic modulations of mycoendophytes for novel bioactive molecules. Biocatal. Agric. Biotechnol. 2018, 16, 663-668. [CrossRef]

37. Chaichanan, J.; Wiyakrutta, S.; Pongtharangkul, T.; Isarangkul, D.; Meevootisom, V. Optimization of zofimarin production by an endophytic fungus, Xylaria sp. Acra L38. Braz. J. Microbiol. 2014, 45, 287-293. [CrossRef] [PubMed]

38. Pacheco Fill, T.; Pallini, H.F.; da Silva Amaral, L.; da Silva, J.V.; Lazarin Bidóia, D.; Peron, F.; Pelegrin Garcia, F.; Vataru Nakamura, C.; Rodrigues-Filho, E. Copper and Manganese Cations Alter Secondary Metabolism in the Fungus Penicillium brasilianum. J. Braz. Chem. Soc. 2016, 27, 1444-1451.

39. Fillat, Ú.; Martín-Sampedro, R.; Macaya-Sanz, D.; Martín, J.A.; Ibarra, D.; Martínez, M.J.; Eugenio, M.E. Screening of eucalyptus wood endophytes for laccase activity. Process Biochem. 2016, 51, 589-598. [CrossRef]

40. Goutam, J.; Sharma, V.K.; Verma, S.K.; Singh, D.K.; Kumar, J.; Mishra, A.; Kumar, A.; Kharwar, R.N. Optimization of Culture Conditions for Enhanced Production of Bioactive Metabolites Rich in Antimicrobial and Antioxidant Activities Isolated from Emericella quadrilineata an Endophyte of Pteris pellucida. J. Pure Appl. Microbiol. 2014, 8, 2059-2073.

41. Li, P.; Xu, L.; Mou, Y.; Shan, T.; Mao, Z.; Lu, S.; Peng, Y.; Zhou, L. Medium optimization for exopolysaccharide production in liquid culture of endophytic fungus Berkleasmium sp. Dzf12. Int. J. Mol. Sci. 2012, 13, 11411-11426. [CrossRef]

42. Mou, Y.; Luo, H.; Mao, Z.; Shan, T.; Sun, W.; Zhou, K.; Zhou, L. Enhancement of palmarumycins C12 and C13 production in liquid culture of endophytic fungus Berkleasmium sp. Dzf12 after treatments with metal ions. Int. J. Mol. Sci. 2013, 14, 979-998. [CrossRef] [PubMed]

43. Nomila Merlin, J.; Nimal Christhudas, I.V.S.; Praveen Kumar, P.; Agastian, P. Optimization of growth and bioactive metabolite production: Fusarium solani. Asian J. Pharm. Clin. Res. 2013, 6, 98-103.

44. Panuthai, T.; Sihanonth, P.; Piapukiew, J.; Sooksai, S.; Sangvanich, P.; Karnchanatat, A. An extracellular lipase from the endophytic fungi Fusarium oxysporum isolated from the Thai medicinal plant, Croton oblongifolius Roxb. Afr. J. Microbiol. Res. 2012, 6, 2622-2638.

45. Sorgatto, M.; Guimaraes, N.C.A.; Zanoelo, F.F.; Marques, M.R.; Peixoto-Nogueira, S.C.; Giannesi, G.G. Purification and characterization of an extracellular xylanase produced by the endophytic fungus, Aspergillus terreus, grown in submerged fermentation. Afr. J. Biotechnol. 2012, 11, 8076-8084. [CrossRef]

46. Zhao, X.-M.; Wang, Z.-Q.; Shu, S.-H.; Wang, W.-J.; Xu, H.-J.; Ahn, Y.-J.; Wang, M.; Hu, X. Ethanol and Methanol Can Improve Huperzine a Production from Endophytic Colletotrichum gloeosporioides ES026. PLoS ONE 2013, 8, e61777. [CrossRef] [PubMed] 
47. Zhao, J.; Wang, X.; Sun, W.; Mou, Y.; Peng, Y.; Zhou, L. Medium optimization for palmarumycin C13 production in liquid culture of endophytic fungus Berkleasmium sp. Dzf12 using response surface methodology. Electron. J. Biotechnol. 2013, 16, 16. [CrossRef]

48. Kaeberlein, T.; Lewis, K.; Epstein, S.S. Isolating “Uncultivable” Microorganisms in Pure Culture in a Simulated Natural Environment. Science 2002, 296, 1127-1129. [CrossRef]

49. Wohlleben, W.; Mast, Y.; Stegmann, E.; Ziemert, N. Antibiotic drug discovery. Microb. Biotechnol. 2016, 9 , 541-548. [CrossRef]

50. Netzker, T.; Fischer, J.; Weber, J.; Mattern, D.J.; König, C.C.; Valiante, V.; Schroeckh, V.; Brakhage, A.A. Microbial communication leading to the activation of silent fungal secondary metabolite gene clusters. Front. Microbiol. 2015, 6, 1-13. [CrossRef]

51. Molinar, E.; Rios, N.; Spadafora, C.; Elizabeth Arnold, A.; Coley, P.D.; Kursar, T.A.; Gerwick, W.H.; Cubilla-Rios, L. Coibanoles, a new class of meroterpenoids produced by Pycnoporus sanguineus. Tetrahedron Lett. 2012, 53, 919-922. [CrossRef]

52. U’Ren, J.M.; Lutzoni, F.; Miadlikowska, J.; Laetsch, A.D.; Elizabeth Arnold, A. Host and geographic structure of endophytic and endolichenic fungi at a continental scale. Am. J. Bot. 2012, 99, 898-914. [CrossRef] [PubMed]

53. Andrews, J.M. BSAC standardized disc susceptibility testing method (version 8). J. Antimicrob. Chemother. 2009, 64, 454-489. [CrossRef] [PubMed]

54. Vásquez, R.; Rios, N.; Solano, G.; Cubilla-Rios, L. Lentinoids A-D, New Natural Products Isolated from Lentinus strigellus. Molecules 2018, 23, 773. [CrossRef] [PubMed]

55. Jorgensen, J.H.; Turnidge, J.D. Susceptibility Test Methods Dilution and Disk Diffusion Methods. In Manual of Clinical Microbiology, 11th ed.; Jorgensen, J., Pfaller, M., Carrol, K., Funke, G., Landry, M., Richter, S., Warnock, D., Eds.; ASM Press: Washington, DC, USA, 2015; pp. 1253-1273.

56. Subban, K.; Subramani, R.; Johnpaul, M. A novel antibacterial and antifungal phenolic compound from the endophytic fungus Pestalotiopsis mangiferae. Nat. Prod. Res. 2013, 27, 1445-1449. [CrossRef]

57. Cutler, H.G.; Himmelsbach, D.S.; Jacyno, J.M.; Cole, P.D.; Yagen, B.; Arrendale, R.F.; Cox, R.H. Koninginin B: A Biologically Active Congener of Koninginin A from Trichoderma koningii. J. Agric. Food Chem. 1991, 39, 977-980. [CrossRef]

58. Ghisalberti, E.L.; Rowland, C.Y. Antifungal Metabolites from Trichoderma harzianum. J. Nat. Prod. 1993, 56, 1799-1804. [CrossRef]

59. Parker, S.R.; Cutler, H.G.; Schreiner, P.R. Koninginin E: Isolation of a Biologically Active Natural Product from Trichoderma koningii. Biosci. Biotechnol. Biochem. 1995, 59, 1747-1749. [CrossRef]

60. Luo, D.-Q.; Deng, H.-Y.; Yang, X.-L.; Shi, B.-Z.; Zhang, J.-Z. Oleanane-Type Triterpenoids from the Endophytic Fungus Pestalotiopsis clavispora Isolated from the Chinese Mangrove Plant Bruguiera sexangula. Helv. Chim. Acta 2011, 94, 1041-1047. [CrossRef]

61. Fu, S.B.; Yang, J.S.; Cui, J.L.; Meng, Q.F.; Feng, X.; Sun, D.A. Multihydroxylation of ursolic acid by Pestalotiopsis microspora isolated from the medicinal plant Huperzia serrata. Fitoterapia 2011, 82, 1057-1061. [CrossRef]

62. Evidente, A.; Amalfitano, C.; Pengue, R.; Altomare, C. High performance liquid chromatography for the analysis of fusapyrone and deoxyfusapyrone, two antifungal $\alpha$-pyrones from Fusarium semitectum. Nat. Toxins 1999, 7, 133-137. [CrossRef]

(C) 2020 by the authors. Licensee MDPI, Basel, Switzerland. This article is an open access article distributed under the terms and conditions of the Creative Commons Attribution (CC BY) license (http://creativecommons.org/licenses/by/4.0/). 